\title{
Effect of stevia (Stevia Rebaudiana L.) leaf extract on the quality and shelf life of lemon (Citrus limon L.)
}

\author{
Abdul Basit ${ }^{1 *}$, Sumbal Ayaz ${ }^{1}$, Abdur Rab ${ }^{1}$, Izhar Ullah ${ }^{1}$, Syed Tanveer \\ Shah $^{1}$, Imran Ahmad ${ }^{1}$, Inayat Ullah ${ }^{2}$ and Muhammad Areeb Khalid ${ }^{1}$ \\ 1. Department of Horticulture, The University of Agriculture, Peshawar-Pakistan \\ 2. Department of Agricultural Mechanization, The University of Agriculture, Peshawar-Pakistan \\ *Corresponding author's email: mashalhort97@gmail.com \\ Citation \\ Abdul Basit, Sumbal Ayaz, Abdur Rab, Izhar Ullah, Syed Tanveer Shah, Imran Ahmad, Inayat Ullah and \\ Muhammad Areeb Khalid. Effect of stevia (Stevia Rebaudiana L.) leaf extract on the quality and shelf life of lemon \\ (Citrus limon L.). Pure and Applied Biology. Vol. 8, Issue 2, pp1456-1468. \\ http://dx.doi.org/10.19045/bspab.2019.80085
}

\begin{tabular}{llll}
\hline \hline Received: 31/01/2019 & Revised: 29/04/2019 & Accepted: 02/05/2019 & Online First: 09/05/2019 \\
\hline
\end{tabular}

\section{Abstract}

Lemon fruit faces lots of disease challenges when subjected to storage. Edible coatings are one of the most environment friendly technology that are used to minimize the moisture loss, oxidation processes or gases exchange, improve quality and shelf life of fruits. To study the influence of stevia leaves extract on post-harvest performance of lemons, a research study was carried out at Post-harvest Horticultural Laboratory, The University of Agriculture, Peshawar-Pakistan. Lemon fruits were subjected to different concentrations of stevia leaf extract $(2,4$ and $6 \%)$ and then stored for different duration $(0,15,30$ and 45 days). The experimental results indicated that stevia leaf extract and storage duration significantly affected all quality attributes. The highest value of TSS, percent titratable acidity, ascorbic acid content with lowest value of fruit juice $\mathrm{pH}$, TSS/Acid ratio and percent disease incidence were recorded in fruit subjected to $4 \%$ stevia extract. Similarly, lemon fruit stored for 45 days had highest value of TSS, TSS/Acid ratio, fruit juice $\mathrm{pH}$, percent disease incidence and \% weight loss. While maximum \% acidity, ascorbic acid content was observed in freshly harvested fruit. It was concluded that lemon fruit subjected to stevia leaf extract (4\%) sustained the biochemical attributes of lemon fruit during storage condition.

Keywords: Blue mold; Edible coating; Quality; Stevia; Stem end rot; Shelf life,

\section{Introduction}

Lemon botanically known as Citrus limon $\mathrm{L}$. belongs to family Rutaceae. The tree has open growth habit with vigorous, upright and spreading canopy [1]. Lemon for the first time was introduced in 200 A.D into southern Italy and spread by 700 A.D to Iraq and Egypt, Spain, India, Argentine, Iraq and U.S which are the top most 5 lemon producing countries [2]. The lemon is believed to be grown in eastern India on lower hills of Himalayan Mountains [3]. For the fruits, diseases are great challenges. During storage lemons are subjected to diseases like stemend rot and many molds such as pink mold [4], green and blue molds as well as sour rot mainly caused by the pathogens Penicillium roseum, $P$. digitatum, P. italicum and Geotricum candidum, respectively [5]. Postharvest decay is the most important factor limits the 
longevity of the juicy products harvested [6]. Postharvest diseases due to fungal infections cause significant economic losses for the citrus industry during storage transport and marketing [7]. In such conditions small sunken areas appear on albedo however, this defect externally not visible [8]. Synthetic chemicals are widely used in the control of plant diseases. However, these chemicals may cause toxic residues in treated products [9]. In order to reduce the pre-harvest and post-harvest treatments of horticultural products with chemical fungicides, new research efforts, focus on this subject are required [10]. For this reason, it is important to use natural ingredients instead of chemicals. Currently various techniques have been practiced such as cold storage, hot water treatment, fungicides application and wrapping to avoid these diseases, postharvest losses and increase the post-harvest life of citrus fruits [11]. These extracts include use of medicinal herbs (plants have phytochemicals in their fruit juice) which is becoming very popular like ginger, garlic and lemon grass. They have their own properties like antioxidant and antimicrobial properties [12]. It is obvious that edible coatings applied on eating products is an environmental friendly technique that controls gaseous exchange, moisture loss and various oxidation processes.

Stevia also known as sweet weed and sugar leaf is a highly valuable and medicinal plant domesticated recently worldwide [13]. Stevia rebaudiana $\mathrm{L}$. belongs to family Asteraceae is a non-caloric natural-source alternative to artificially produced sugar substitutes. These compounds easily pass through the digestive process without chemically breaking down, making stevia safe for those who need to control their blood sugar level [14]. It provides an additional coating layer that protects the fruit by providing a modified atmosphere. Stevia has sweet taste, antioxidant [15] and anti-pathogenic characteristics. Stevia leaf extract in different concentration are used for the purpose of better quality and to increase shelf life of the fruit. The dry product obtained from the stevia leaves contains different compounds like amino acids, oligosaccharides, flavonoids, alkaloids, xanthophyll, chlorophylls, free sugars, lipids and trace elements [16]. Stevia plant leaves also have an antifungal effect [17] while used for postharvest effects $[18,19]$.

The present research was designed to determine the influence of appropriate stevia leaf extract for better fruit quality of lemon fruit during storage.

\section{Materials and methods}

\section{Experimental site and procedure}

To investigate the effect of stevia extract and storage duration on quality shelf life of lemons, an experiment was carried out at Post-harvest Horticultural Laboratory, The University of Agriculture, Peshawar. The research was laid out in Completely Randomized Design (CRD) with two factors having three repetition. Freshly harvested uniformly sized lemon fruits were dipped in different stevia leaf extract solution $(0,2,4$ and $6 \%$ ) for few minutes and then stored for different storage duration $(0,15,30$ and 45 days) at room temperature and relative humidity.

Preparation of Stevia leaf extract solution Freshly harvested leaves were dried in oven for 24 hours. Then $100 \mathrm{~g}$ of stevia dry leaves were taken and grinded it into electric grind mixer. Finally, the solution of different concentration $2 \%, 4 \%, 6 \%$ were prepared separately in $500 \mathrm{ml}$ of water.

\section{Studied parameters}

Total soluble solids ( ${ }^{0}$ Brix) content in fruit juice was determined through hand refractometer. Titratable acidity was determined by using neutralization reaction as described in [20]. The total soluble solids/ acid ratio was measured by using the following formula: 


$$
\text { TSS } / \text { Acid ratio }=\frac{\text { Total soluble Solid }\left({ }^{\circ} \text { Brix }\right)}{\text { Titratable Acidity }(\%)}
$$

Fruit juice $\mathrm{pH}$ in each replications of all treatments was determined by using an electronic $\mathrm{pH}$ meter for the interval of 15 days. Prior to use the $\mathrm{pH}$ meter, its $\mathrm{pH}$ was adjusted to 7 by washing the tip of $\mathrm{pH}$ meter with tap water. Juice were extracted through a manual juicer from the randomly selected fruits and the juice were taken in a beaker for finding its $\mathrm{pH}$. Ascorbic acid (mg/100g) was determined by using Dye method as described by [21]. Percent Disease incidence per treatments was calculated after 15 days of interval with the help of given formula.

$$
\% \text { Disease incidence }=\frac{\text { Total number of diseased fruits }}{\text { Total number of fruits }} \times 100
$$

From each treatment five fruits were randomly taken to test its weight loss. Initial weight of fruits was recorded by using digital balance (Ohaus scale corp, USA) as used by [22] for root weight of guava air-layers.
Average weight loss of fruits was recorded in all treatments for an interval of 15 days. Fruit weight loss was determined by using the given formula.

$$
\% \text { Weight loss }=\frac{\text { Fresh fruit wt. }(g)-\text { fruit wt. after storage duration }(g)}{\text { Wt. of fresh fruit }(g)} \times 100
$$

\section{Data analysis}

The data taken for different variable were subjected to Analysis of Variance (ANOVA), suitable for Completely Randomized Design (CRD) using a statistical package Statistics 8.1 (Statistix, an Analytical Software) as suggested by [23] and with two factorsfactorial arrangement.

\section{Results and discussion \\ Total soluble solids ( ${ }^{\circ}$ Brix)}

Stevia leaf extract, storage duration and their interaction significantly affected the TSS (Total Soluble Solid) of lemon fruit (Table 1). Fruits treated with $4 \%$ stevia extract showed maximum TSS content $\left(7.65^{\circ}\right.$ brix) followed by $\left(7.57^{\circ}\right.$ Brix) fruit treated with $6 \%$ stevia extract. Whereas, minimum TSS content $\left(7.55^{\circ}\right.$ Brix) was noted in fruits treated with $2 \%$ stevia extract that was statistically at par with $\operatorname{TSS}\left(7.55^{\circ}\right.$ Brix $)$ in untreated fruits respectively. Similarly maximum TSS content $\left(9.34^{\circ}\right.$ Brix) was noted for storage duration of 45 days interval followed by $\left(8.06^{\circ} \mathrm{Brix}\right)$ and $\left(6.86^{\circ} \mathrm{Brix}\right)$ noticed in fruits stored for 30 and 15 days respectively. However, minimum TSS content $\left(6.05^{\circ}\right.$ Brix $)$ was found in freshly harvested fruit. Regarding interaction, maximum TSS content $\left(9.45^{\circ}\right.$ Brix $)$ was observed in untreated fruits stored for 45 days of interval and minimum TSS content $\left(6.02^{\circ}\right.$ Brix) was observed in untreated freshly harvested fruits (Figure 1). This might be due to higher respirational of the fruits with no protective layer to control the gaseous diffusion in and out of fruits. [24] found that increase in TSS and sugar contents during storage of produce might be due to hydrolysis of the insoluble complex carbohydrates into simple sugar. The increment in total soluble solids of fruits might be due to high rate of respiration and metabolic activity which enhance the breakdown of protopectin to pectic substance, disaccharides to monosaccharides and sucrose to fructose and glucose [25]. The higher respiration rate increases the synthesis and use of metabolites result in higher TSS due to the more conversion of carbohydrates to sugars. The degradation of pectin, hemicelluloses and cellulose in cell wall within the segment release some soluble constituent which have 
a direct effect on total soluble solids [26]. Where these changes could be expected more gradual and slower if the metabolic activities are slow down by applying phyto-coatings [27]. [28] studied that highest mean TSS contents among all treatments were recorded in response to fruits treated with $4 \%$ stevia extract whereas, they were lowest in control fruits.

Table 1. Influence of Stevia leaf extract and Storage duration on quality attributes of lemon fruit

\begin{tabular}{|c|c|c|c|c|c|c|c|}
\hline $\begin{array}{c}\text { Stevia leaf } \\
\text { extract }\end{array}$ & $\begin{array}{c}\text { Total } \\
\text { Soluble }\end{array}$ & $\begin{array}{c}\text { Percent } \\
\text { titratable }\end{array}$ & TSS/Acid & Fruit & $\begin{array}{l}\text { Ascorbic } \\
\text { acid }\end{array}$ & Percent & Fruit \\
\hline $\begin{array}{l}\text { Concentrati } \\
\text { on (ME) }\end{array}$ & $\begin{array}{c}\text { Solid } \\
\left({ }^{0} \text { Brix }\right)\end{array}$ & $\begin{array}{c}\text { acidity } \\
(\%)\end{array}$ & ratio & Juice pH & $\begin{array}{c}\text { content } \\
\left(\mathrm{mg100g}^{-1}\right)\end{array}$ & $\begin{array}{l}\text { Disease } \\
\text { Incidence }\end{array}$ & $\begin{array}{l}\text { Wess }(\%) \\
\text { loss }\end{array}$ \\
\hline $0 \%$ & $7.55 \mathrm{c}$ & $3.43 \mathrm{c}$ & $2.4 \mathrm{a}$ & $3.26 \mathrm{~b}$ & $11.8 \mathrm{~d}$ & $19.4 \mathrm{a}$ & $23.9 \mathrm{~b}$ \\
\hline $2 \%$ & $7.55 \mathrm{c}$ & $4.02 \mathrm{a}$ & $1.9 \mathrm{c}$ & $3.30 \mathrm{a}$ & $13.8 \mathrm{~b}$ & $2.8 \mathrm{~b}$ & $22.57 \mathrm{c}$ \\
\hline $4 \%$ & $7.65 \mathrm{a}$ & $4.10 \mathrm{a}$ & $1.9 \mathrm{c}$ & $3.27 \mathrm{~b}$ & $14.2 \mathrm{a}$ & $8.3 \mathrm{~b}$ & $21.17 \mathrm{~d}$ \\
\hline $6 \%$ & $7.57 \mathrm{~b}$ & $3.61 b$ & $2.2 \mathrm{~b}$ & $3.25 \mathrm{c}$ & $13.2 \mathrm{c}$ & $8.3 \mathrm{~b}$ & $24.1 \mathrm{a}$ \\
\hline LSD $\leq 0.05$ & 8.31 & 0.07 & 0.05 & 8.31 & 0.10 & 9.90 & 0.07 \\
\hline \multicolumn{8}{|c|}{ Storage duration (S.D } \\
\hline $\mathbf{0}$ & $6.05 d$ & $4.63 \mathrm{a}$ & $1.31 \mathrm{~d}$ & $3.04 \mathrm{~d}$ & $20.68 \mathrm{a}$ & $8.33 \mathrm{~b}$ & Od \\
\hline 15 & $6.86 c$ & $3.93 \mathrm{~b}$ & $1.75 \mathrm{c}$ & $3.20 \mathrm{c}$ & $13.79 \mathrm{~b}$ & $0.00 \mathrm{c}$ & $21.32 \mathrm{c}$ \\
\hline 30 & $8.06 \mathrm{~b}$ & $3.44 \mathrm{c}$ & $2.37 \mathrm{~b}$ & $3.32 b$ & $10.45 \mathrm{c}$ & $5.55 b$ & $26.57 b$ \\
\hline 45 & $9.34 \mathrm{a}$ & $3.17 \mathrm{~d}$ & $3.00 \mathrm{a}$ & $3.52 \mathrm{a}$ & $8.16 \mathrm{~d}$ & $24.98 \mathrm{a}$ & $43.85 \mathrm{a}$ \\
\hline $\mathrm{LSD} \leq 0.05$ & 8.31 & 0.07 & 0.05 & 8.31 & 0.10 & 9.90 & 0.07 \\
\hline \multicolumn{8}{|l|}{ Interaction } \\
\hline$\overline{M E \times S . D}$ & Figure 1 & Figure 2 & Figure 3 & Figure 4 & Figure 5 & Figure 6 & Figure 7 \\
\hline
\end{tabular}

Means value followed by dissimilar letters differ significantly at $5 \%$ level of significance

\section{Percent titratable acidity}

It is obvious from (Table 1) that stevia leaf extract, storage duration and their interaction significantly affected percent titratable acidity of lemon fruit. Fruits treated with $4 \%$ stevia extract showed maximum percent titratable acidity (4.10\%) followed by titratable acidity $(4.02 \%)$ and $(3.61 \%)$ in fruits treated with $2 \%$ and $6 \%$ stevia leaf extract respectively. Whereas, minimum $(3.43 \%)$ titratable acidity was noted in untreated fruit. Data pertaining to storage durations, maximum titratable acidity $(4.63 \%)$ was observed in freshly harvested fruit followed by fruits stored for 15 and 30 days $(3.93 \%)$ and $(3.44 \%)$ respectively. However, the minimum titratable acidity $(3.17 \%)$ was noted in fruit stored for 45 days. Concerning interaction, maximum percent titratable acidity $(4.77 \%)$ was observed in freshly harvested fruits treated with $4 \%$ stevia extract. Whereas minimum percent titratable acidity $(2.58 \%)$ was noted in untreated fruits that were stored for 45 days (Figure 2). It is obvious from the results that increase in concentration of extract cause increase in titratable acidity. During storage reduction in titratable acidity of juice occur due to use of acid as source of energy which converts organic acid to form sugar [29]. During storage, rate of respiration increases which consume organic acid and reduce the fruit acidity that affect the fruit flavor [30]. According to [31] decrease in total acidity is usual during postharvest storage of fruit. They studied that highest acidity was recorded at $4 \%$ stevia extract during storage duration. Generally, citrus juice contain significant amount of organic acids like oxalic, tartaric, malic, lactic, citric and 
ascorbic acid but citric acid are considered as the most abundant acid of total acid constituent of juice followed by malic acid.

\section{TSS/acid ratio}

It is obvious from (Table 1) that TSS/acid ratio was significantly affected by stevia leaf extract, storage duration and their interaction. Maximum TSS/acid ratio (2.4) was recorded in freshly harvested fruit followed by fruits treated with $6 \%$ stevia extract (2.2). While the minimum TSS/acid ratio (1.9) was noted in fruits treated with $2 \%$ and $4 \%$ stevia extract. Similarly maximum TSS/acid ratio (3.00) was found in fruit stored for 45 days of duration followed by (2.37) and (1.75) observed in the fruit kept for 30 and 15 days respectively. Whereas the minimum TSS/acid ratio (1.31) was recorded in fruits taken freshly. Regarding interaction, the maximum TSS/acid ratio (3.7) was noted in freshly harvested fruit, stored for 45 days. While the minimum TSS/acid ratio (1.3) was observed in treated fruits of all concentrations and were freshly harvested (Figure 3). The higher change in TSS/Acid ratio might be due to hydrolytic changes in the starch concentration (conversion of starch to sugar) [32] and decline in organic acids due to its consumption in respiration $[33,34]$. TSS/acid ratio in fruit juice significantly increased by increasing storage period [35]. Fruit having low index of (TSS/TA) are having sour taste, while those having high index value are unpleasant. During extending storage duration the increased TSS/Acid ratio could be due to increased TSS and nearly decrease in acidity after getting maturity. Similarly, [36] observed the same findings in peach cv. Flordasun.

\section{Fruit Juice pH}

Stevia leaf extract, storage interval and their interaction significantly affected the $\mathrm{pH}$ of fruit juice (Table 1). Fruits treated with $4 \%$ stevia extract had the maximum value of fruit juice $\mathrm{pH}$ (3.27) followed by (3.26) and (3.30) fruits treated with $0 \%$ and $2 \%$ stevia extract respectively. However, the minimum $\mathrm{pH}$ of fruit juice (3.25) was noted in the fruits treated with $6 \%$ stevia extract. Similarly, the maximum fruit juice $\mathrm{pH}$ (3.52) was observed in fruit stored for 45 days followed by fruit juice $\mathrm{pH}$ (3.32) and (3.20) recorded in stored fruits at 30 and 15 days of interval. Whereas, minimum fruit juice $\mathrm{pH}$ (3.04) was found in freshly harvested fruit. Regarding interaction, maximum value of fruit juice $\mathrm{pH}$ (3.63) was observed in all untreated fruits which were kept for 45 days of interval. However, the minimum fruit juice $\mathrm{pH}$ (3.02) was noted in treated fruits of $2 \%$ stevia extract (Figure 4). It was observed that fruit juice $\mathrm{pH}$ decreased with the increase in concentration which may be due to the fermentation of sugar but increase with the increase in storage duration. The change in fruit juice $\mathrm{pH}$ may be due to the reason pectin breakdown to pectenic acid. The determination of fruit juice $\mathrm{pH}$ is done by evaluating the hydrogen ion concentration in the fruits. The given results showed a decline in the value of lemon fruits affected by stevia concentrations and storage duration. During storage catabolic processes increases due to high rate of respiration that cause breakdown of organic acids and thus results high $\mathrm{pH}$ [37]. Similar decline in fruit juice $\mathrm{pH}$ for apple pulp also was reported by [31].

\section{Ascorbic acid content (mg/100g)}

The ascorbic acid content was significantly influenced by stevia leaf extract, storage duration and their interaction (Table 1). Fruits treated with $4 \%$ stevia extract had the maximum ascorbic acid content $(14.2 \mathrm{mg} / 100 \mathrm{~g})$ followed by ascorbic acid content $(13.8,13.2 \mathrm{mg} / 100 \mathrm{~g})$ observed in fruit treated with $2 \%$ and $6 \%$ stevia extract respectively. The lowest ascorbic acid content $(11.8 \mathrm{mg} / 100 \mathrm{~g})$ was noted in treated fruit of $0 \%$ stevia extract. In case of storage duration, maximum ascorbic acid content $(20.68 \mathrm{mg} / 100 \mathrm{~g})$ was recorded in fresh fruit followed by ascorbic acid (13.79, 
$10.45 \mathrm{mg} / 100 \mathrm{~g}$ ) noticed in the lemon fruits stored for 45 days of interval. While minimum ascorbic acid content (8.16 $\mathrm{mg} / 100 \mathrm{~g}$ ) was found in fruit stored for 45 days. Data pertaining interaction showed that maximum ascorbic acid content $(20.49 \mathrm{mg} / 100 \mathrm{~g})$ was noted in freshly harvested fruit treated with $2 \%$ stevia extract. However, lowest ascorbic acid content $(5.97 \mathrm{mg} / 100 \mathrm{~g})$ was observed in untreated lemon fruits that were stored for 45 days (Figure 5). It was observed that with the increasing concentration of stevia extract as a single treatment the level of ascorbic acid content was also increased. By the extension of storage period the vitamin $\mathrm{C}$ content decreases progressively $[35,38]$. Fruits coated with Stevia extract coating maintained maximum ascorbic acid. The higher ascorbic acid content might be due to high metabolic activities. Similarly, [39] also observed that reduction in respiration rate was contributed by pure castor and coconut oil coatings, resulted in dissoluteness of acids to dehydroascorbic acid when stored for interval. During storage decline in Vitamin $\mathrm{C}$ occur above $0^{\circ} \mathrm{C}$ temperature [40]. Decrease in ascorbic acid content may also be due to antioxidants activity loss during pot-harvest storage [41]. Ascorbic acid decreased in fruits by increasing storage duration. Present research findings are in accordance with those of [42] who reported that ascorbic acid of sweet orange decreased with extending storage duration.

\section{Percent disease incidence}

Citrus fruit are highly perishable and have high disease incidence. The analysis of data indicated that percent disease incidence was significantly affected by stevia leaf extract, storage duration and their interaction (Table 1). Maximum value of percent disease incidence (19.4\%) was observed in freshly harvested fruit followed by percent disease incidence $(8.3 \%)$ noted in fruits treated with 6 and $4 \%$, of stevia leaf extract, while minimum value of percent disease incidence was recorded in $(2.8 \%)$ at $2 \%$ stevia leaf extract. In case of storage duration, highest percent disease incidence $(24.98 \%)$ was recorded in stored fruits for 45 days followed by percent disease incidence $(8.33 \%)$ observed in lemon fruit stored for 30 days. While minimum disease incidence $(0.00 \%)$ was recorded in fruit stored for 15 days of storage duration. Regarding interaction, maximum percent of disease incidence $(44.4 \%)$ was noted in fruits which were untreated and kept for 45 days of interval. While minimum percent disease incidence $(0.00 \%)$ was also observed in fruits treated with all concentrations and were stored for 15,30 days and also in freshly harvested fruits (Figure 6). The increment in percent disease incidence during storage period could be due to high respiration rate, more skin permeability for water loss, fruit senescence, enzymatic degradation of fruits cell wall and high susceptibility to decay [43]. The highest percent disease incidence might be due to accumulation of moisture around the fruit that provide favorable environments for microbial growth and thus aggravate spoilage [44]. The higher spoilage with fruit harvested at more mature stages might due to the more enzymatic activities and disintegration of cell wall [45]. As level of stevia extract and storage duration were increased, the percentage of weight loss and decay, were decreased because stevia extract along with 30 days storage there were little bit signs of disease or decay [46]. [47] reported that percent disease incidence of fruit increased with increasing storage duration

\section{Percent weight loss}

Statistical analysis of data revealed that percent weight loss was significantly affected by stevia leaf extract, storage duration and their interaction (Table 1). Fruits treated with $6 \%$ stevia extract showed maximum percent weight loss (24.1\%) followed by (23.9\%) and $(22.7 \%)$ in lemon fruits treated with $0 \%$ and 
$2 \%$ stevia extract. Whereas, the minimum percent weight loss $(21.17 \%)$ was observed in fruits applied with $4 \%$ of stevia extract. This may be because a waxy layer is created on the fruits due to stevia extract, which may cover the pores to prevent evapotranspiration. Regarding storage duration, the maximum weight loss in fruits was noted in fruits stored for 30 and 15 days. Whereas, the minimum fruit weight loss $(0 \%)$ was observed in fruits harvested freshly. However, interaction of stevia leaf extract and storage duration showed that maximum weight loss $(45.8 \%)$ was observed in fruit that were untreated and kept for 45 days of storage duration (Figure 7). Coating treatments with stevia extracts caused significant reduction in weight loss and the most effective treatments in this regard was $4 \%$ stevia extract. According to [48], coating with stevia extracts might form a very fine coating that acts as a semi-permeable membrane to normalize the $\mathrm{CO}_{2}$ and $\mathrm{O}_{2}$ diffusion into and out of fruits. It also prevent reduction in metabolism rate and water loss as well. The increase in weight loss during storage might be due to loss of moisture which reduced fruit turgidity [49] and enhanced fruit softening [50] and also due to starch conversion into soluble solids [51]. The water loss from the citrus fruit are closely related with many physiological [52] and rind disorders [53]. The results are in correspondence with [54] who recorded an increase in weight loss due to increase in storage period. He also observed that weight loss in fruits treated with Stevia extract was statistically lower than those treated with karbandazim, a chemical fungicide.

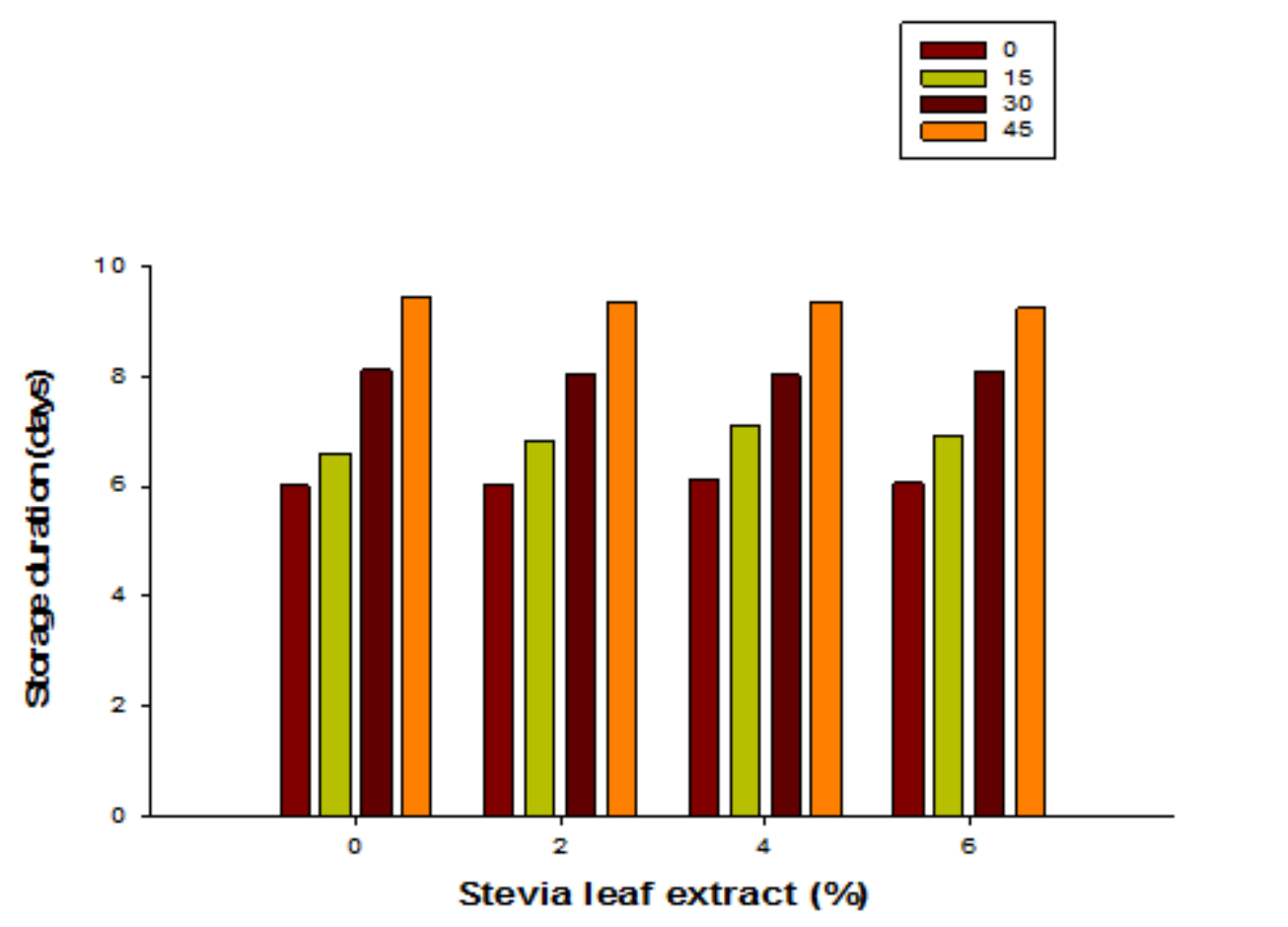

Figure 1. Total soluble solid of lemon fruit as influenced by interaction of stevia leaf extract and storage duration 


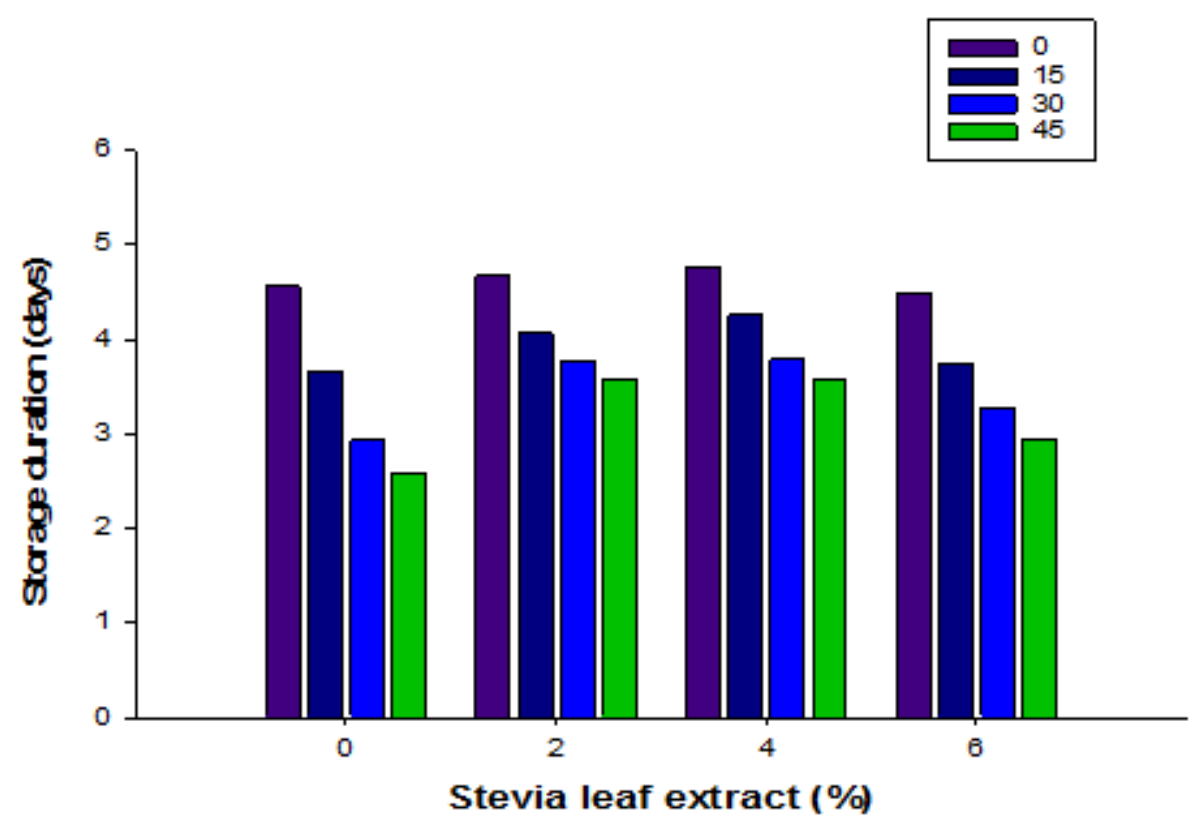

Figure 2. Percent titratable acidity of lemon fruit as influenced by interaction of stevia leaf extract and storage duration

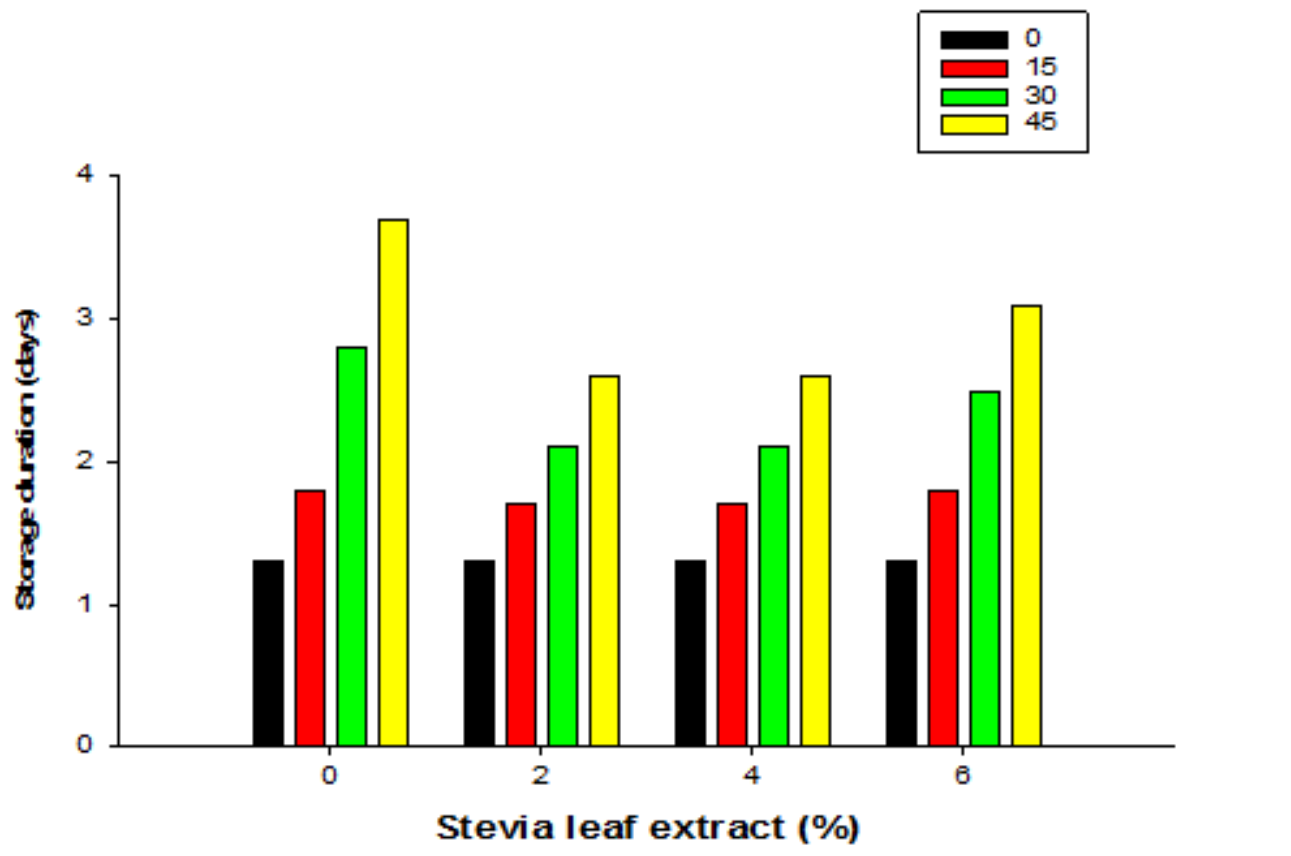

Figure 3. TSS/Acid ratio of lemon fruit as influenced by interaction of stevia leaf extract and storage duration 


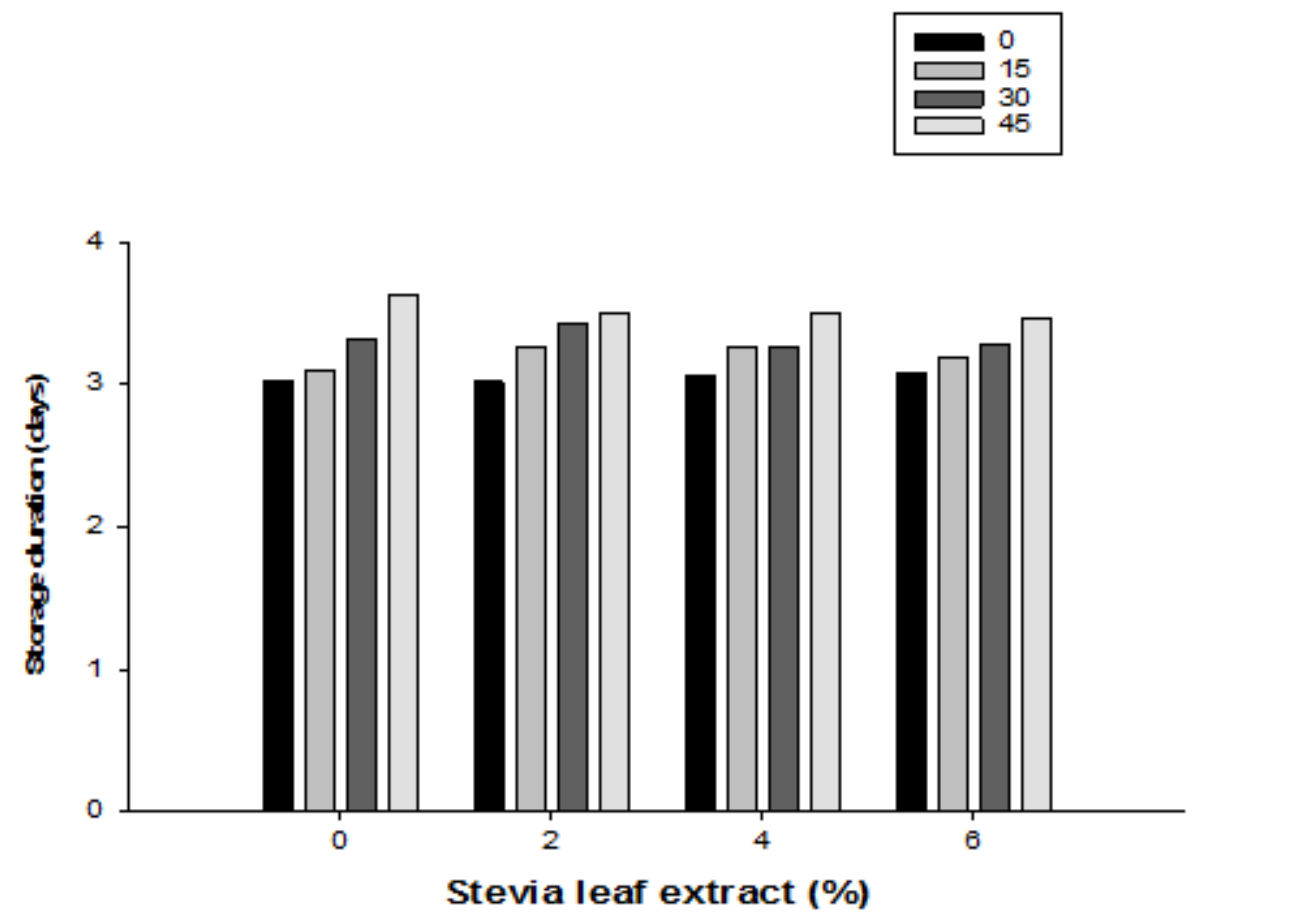

Figure 4. Fruit juice pH of lemon fruit as influenced by interaction of stevia leaf extract and storage duration

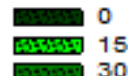

$$
\begin{aligned}
& \text { एक } 45
\end{aligned}
$$

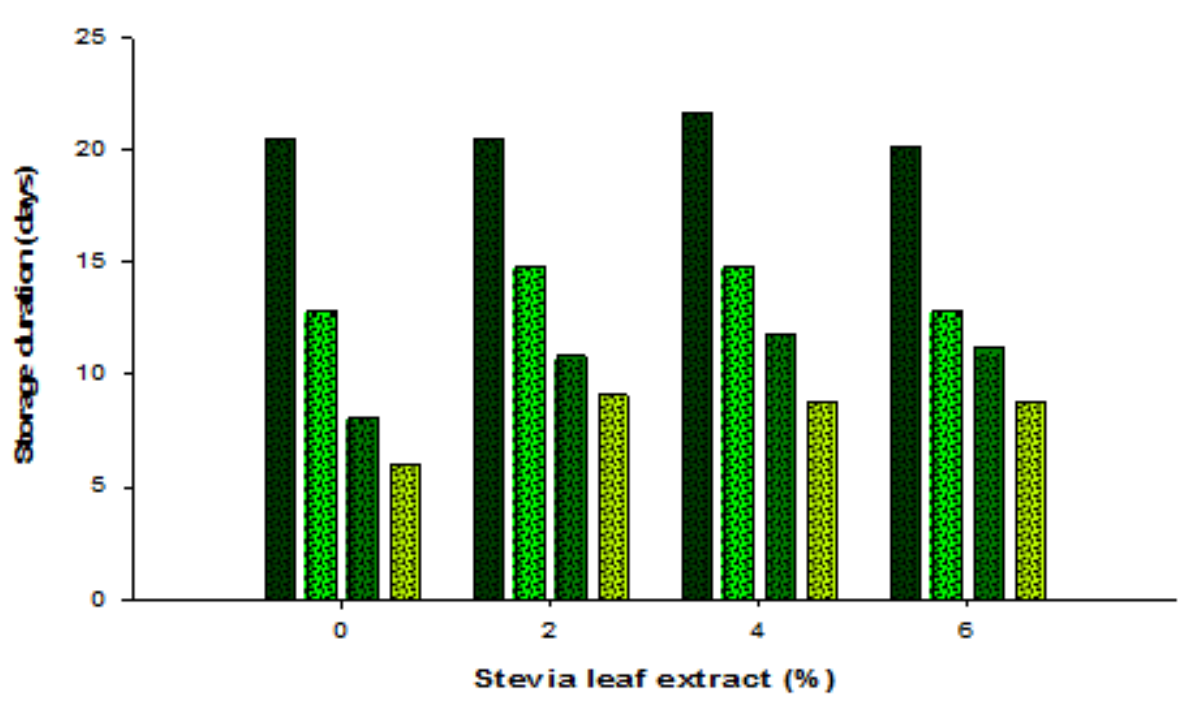

Figure 5. Ascorbic acid content of lemon as influenced by interaction of stevia leaf extract and storage duration 
Basit et al.

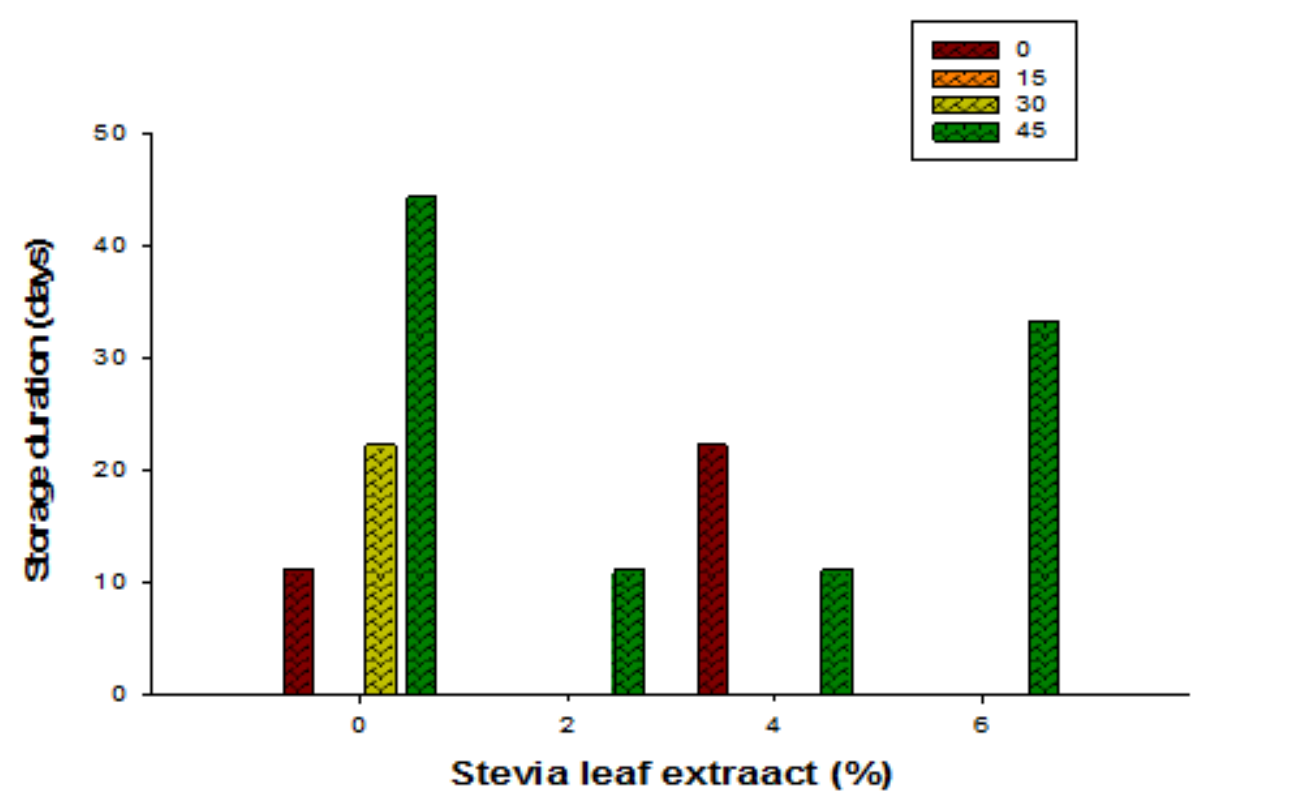

Figure 6. Percent disease incidence of lemon fruit as influenced by interaction of stevia leaf extract and storage duration
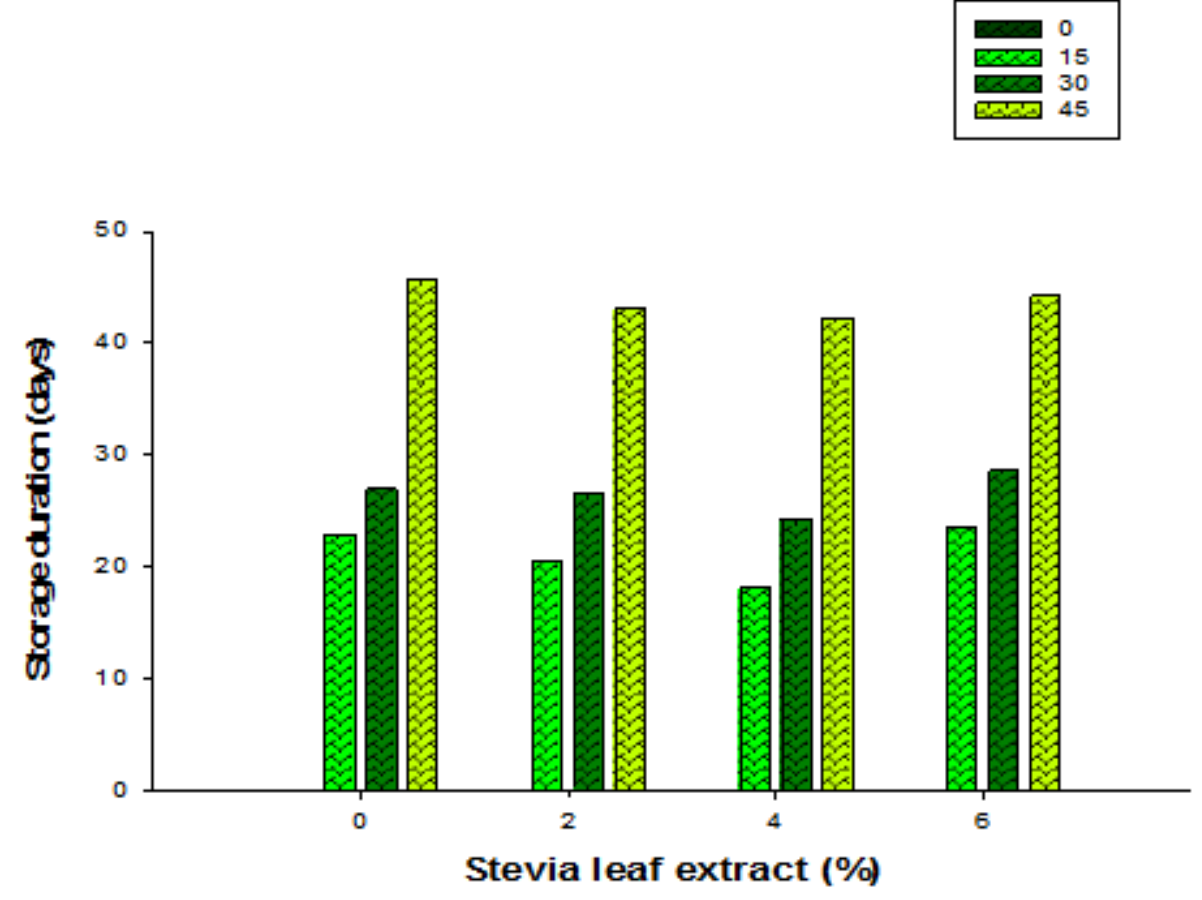

Figure 7. Fruit weight loss of lemon fruit as influenced by interaction of stevia leaf extract and storage duration 


\section{Conclusion}

It can be concluded that the most effective treatments in maintaining quality attributes like TSS, acidity, fruit juice $\mathrm{pH}$, ascorbic acid content in lemons when treated with $4 \%$ stevia extract. Fruits treated with $4 \%$ extract were also effective in decrease in weight loss of fruits and also controlling disease incidence. Regarding storage intervals, quality attributes of lemon sustained for 30 days interval but a gradual decline was observed after 30 days. On the basis of results, it could be recommended that coating of lemons with $4 \%$ stevia extract sustained quality attributes of lemon fruit for about 30 days at room temperature and relative humidity.

\section{Authors' contributions}

Conceived and designed the experiments: A Rab \& S Ayaz, Performed the experiments: A Basit \& S Ayaz, Analyzed the data: A Basit, I Ullah \& S.T. Shah, Contributed materials/ analysis/ tools: S Ayaz, I Ullah, MA Khalid \& I Ahmad, Wrote the paper: A Basit \& I Ullah

\section{References}

1. Tucker DPII \& Wardowski WF (1976). Lemon production and utilization in Florida. Bull.184.Fla.Coop.Ext.Serv. IFAS. Uni of Florida. Gainesville.

2. Anonymous (2004). Commonly highlighted, lemon production and consumption Economic Res, service, fruit and tree nuts outlook/FTS-310, pp16-19.

3. Davis FS \& Albrigo LG (1994). Citrus ISBN \#0-85 988679, pp 41-43: 220-221.

4. Ladaniya MS (2008). Citrus fruit: biology, technology and evaluation. Academic press is an imprint of Elsevier. USA, pp 594.

5. El-Mougy NS, El-Gamal NG \& Abd-ElKareem F (2008). Use of organic acids and salts to control postharvest diseases of lemon fruits in Egypt. Arch. Phytopathol. Plant Protect 41 (7): 467-476.

6. Eckert JW \& Ogawa JM (1988). The chemical control of post-harvest diseases, decidous fruits, berries, vegetable and root tuber crops. Ann Rev Phytopatho 26: 433469.

7. Solaimani B, Ramezani S, Rahemi M \& Saharkhiz MJ (2009). Biological control of postharvest disease caused by $P$ digitutum and $P$. italicum on stored citrus fruits by Shiraz Thyme essential oil. $A d v$ in Environ Bio 3(3): 249-254

8. Morton JF (1987). Fruits of warm climate, JF Morton publisher. ISBN\#0-9610184-10, pp 160-168.

9. Isman MB (2000). Plant essential oils for pest and disease management. Crop Protec 19: 603-608.

10. Mironescu M \& Georgescu C (2008). Preliminary researches on the effect of essential oils on moulds isolated from surfaces. $J$ of Agroalimentary processes and Technol 14: 30-33

11. Schirra M, Agabbio M, Hallewin PMD \& Ruggui R (1997). Response of torocco oranges to picking date, postharvest hot water dips and chilling storage temperature. J Agr Food \& Chem 45(8): 3216-3220.

12. Chaisawadi S, Thongbute D, Methawiriyaslip D, Pitakworarat N, Chaisawadi A, Jaturonrasamee K, Khemkhaw J \& Thnuthumchareon W (2003). Preliminary study of antimicrobial activities on medicinal herbs of thai food ingredients. Acta Hortic 675: 111-114.

13. Basit A, Ullah I, Shah ST, Ullah I, Alam N \& Gilani SAQ (2019). Effect of Media Amendments on Invivo Root and Shoot Organogenesis of Stevia (Stevia Rebaudiana). Inter J Biosci 14(4): 55-63.

14. Strauss S (1995). The perfect sweetener. Technol Rev 98: 18-20.

15. Ahmad N, Fazal H, Abbasi BH \& Iqbal M (2011). Invitro aruicidal potential against and anopheles stephensi and antioxidative enzyme activities of Ginkgo biloba, stevia rehaudiana and $P$. hysterophorous. Asain Pac J Trop Med 4: 169-175.

16. Goettemoeller J \& Ching A (1999). Seed germination in Stevia rebaudiana. 
Perspectives on new crops and new users. J Janick (Ed.), ASHS Press. Alexandria, VA.

17. Komissarenko NF, Derkach AI, Kovalyov IP \& Bublik NP (1994). Diterpene glycosides and phenylpropanoids of Stevia rebaudiana Bertoni: Rast Res 1(2): 53-64

18. Tadhani MB \& Subhash R (2006). In vitro Antimicrobial Activity of Stevia rebaudiana Bertoni Leaves. Tropic $J$ Pharmaceut Res 5(1): 557-560

19. Anonymous (2007). Stevia. Raintree Nutrition Tropical Plant Data- base. http://www.rain-tree.com/stevia.htm

20. AOAC (1990). Association of Official Agriculture Chemist Official Methods of Analysis. $9^{\text {th }}$ Ed. 832.

21. Rangana S (1976). In: Manual of analysis of fruits and vegetable products McGraw Hill New Delhi, pp 77.

22. Gilani SAQ, Shah K, Ahmed I, Basit A, Sajid M, Bano AS, Ara G \& Shahid U (2018). Influence of indole butyric acid (IBA) concentrations on air layerage in guava (Psidium guajava L.) cv. Sufeda. Pure Appl Bio 8(1): 355-362.

23. Basit A, Shah K, Rahman MU, Xing L, Zuo X, Han M, Alam N, Khan F, Ahmed I \& Khalid MA (2018). Salicylic acid an emerging growth and flower inducing hormone in marigold (Tagetes sp). Pure Appl Bio 7(4): 1301-1308.

24. Borthakar PK, Kumar, Ranjit \& Kumar RD (2002). Effect of plant extracts on size and rind thickness of Baramasi lemon fruits (Citrus limon L) during storage. $J$ Agric Sci Soc North-East India 15(1): 98103.

25. Sharma RR, Pal RK \& Rana V (2012). Effect of heat shrinkable films on storability of kiwifruits under ambient conditions. Indian J Hort 66: 404-408.

26. Echeverria E \& Ismail M (1990). Sugar unrelated to ${ }^{\circ}$ Brix changes in stored citrus fruits. Hort Sci 25: 710-716.

27. Malik AA, Ahmed N, Babita, Chauhan H \& Gupta P (2016). Plant Extracts in PostHarvest Disease Management of Fruits and Vegetables-A Review. J Food Process Technol 7: 592.

28. Singh JN, Acharya P \& Singh BB (2000). Effect of $\mathrm{GA}_{3}$ and plant extracts on storage behavior of mango (Manifera indica) cv. Langra. Haryana. J Hort Sci 29(3-4): 12129.

29. Karadeniz F (2004). Main organic acid distribution of authentic citrus juices in Turkey. Turk J Agric For 28: 267-271.

30. Ali A, Muhammad M, Sijam K \& Siddiqui Y (2011). Effect of chitosan coating on the physicochemical characteristics of Eksotika II papaya (Carica papaya L.) fruit during cold storage. J Food Chem 124: 620-625.

31. Muhammad A, Ayub M, Durrani Y, Ullah J \& Afridi S (2011). Fruit juice physicochemical analysis of apple pulp from Mashaday variety during storage. Agric \& Bio J North America 2: 192196.

32. Beaudry RM, Severson RF, Black CC, Kays SJ (1989). Banana ripening: implications of changes in glycolytic intermediate concentrations, glycolytic and gluconeogenic carbon flux, and fructose 2,6-bisphosphate concentration. $J$ Plant Physiol 91: 1436-1444.

33. Ghafir SAM, Gadalla SO, Murajei BN \& El- Nady MF (2009). Physiological and anatomical comparison between four different apple cultivars under coldstorage conditions. Afri J Pl Sci 3: 133138.

34. Mahajan (1994). Biochemical and enzymatic changes in apple during cold storage India. J of Food Sci \& Technol 31: 142-152.

35. Eman AAA \& Magda AA (2006). Effect of some oil emulsions and wax treatment on prolonging storage period of Washington navel orange fruits and its volatile components. J Appl Sci Res 2(7): 405-417.

36. Dhillon WS \& Cheema SS (1991). Physico-chemical changes during development of peach cv. Flordasun. Indian Food Packer 56-59. 
37. Riveria J (2005). Cutting shape and storage temperature affect overall quality of fresh cut papaya cv. Maradol. J Food Sci 70(7): 488-489.

38. Rana GS, Kartar SD \& Singh K (1992). Studies on extending postharvest life of sweet orange fruits. Crop Res 5: 154-157.

39. El-Monem EA, Mostafa A \& El-Maged RD (2003). Effect of harvest treatments on storage behaviour of guava fruits cv. Sardar. J Maharashtra Agric Uni 26: 297300.

40. Ajibola VO, Babatunde OA \& Sulemain $\mathrm{S}$ (2009). The effect of storage methods on the Vitamin $\mathrm{C}$ content in some Tropical fruit juices. Inter J Agr Policy and Res 1(7): 197-2004.

41. Davey MW, Montagu MV, Inze D, Sanmartin M, Kanellis A, Smirnoff N, Benzie IJJ, Strain JJ, Favell D \& Fletcher J (2000). Plant L-ascorbic acid: chemistry, function, metabolism, bioavailability and effects of processing. $J$ Sci Food and Agric 80: 825-860.

42. Rab A, Sajid M, Khan NU, Nawab K, Arif M \& Khattak MK (2012). Influence of storage temperature on fungal prevalence and quality of citrus fruit (Cv. Blood Red). Pak J Bot 44(2): 831-836.

43. Ciccarese A, Stellacci M, Gentilesco G \& Rubino P (2013). Effectiveness of pre- and post-harvest calcium applications to control decay and maintain table grape fruit quality during storage. $J$ Postharvest Bio Technol 75: 135-141.

44. Jawandha SK, Gill MS, Singh NP, Gill PPS \& Singh N (2012). Effect of postharvest treatment of putrescine on storage of mango cv. Langra. Afr $J$ Agric Res 7: 6432-6436.

45. Navjot G \& Sukhjit KJ (2010). Influence of maturity stage on fruit quality during storage of 'Early Grande' peaches. Not Sci Biol 2(3): 96-99.
46. Ahmad D, Nadeem M, Rafique M \& Shabbir A (2015). Development and application of edible skin coatings to improve the quality of Kinnow during storage. Ayub Agriculture Institute, Faisalabad, Pakistan.

47. Schirra M, D'hallewin G, Ben-Yehoshua S \& Fallik E (2000). Host-pathogen interactions modulated by heat treatment. Postharvest Biol Tech 21(1): 71-85.

48. Smith SM \& Stow JR (1994). Potential of a sucrose ester coating material for improving the storage and shelf life qualities of "Cox's Orange Pippin". Ann Appl Ecol 104(2): 383-387.

49. Vander Valk AG (1981). Succession in wetlands: a gleasonian appraoch. Ecolo 62(3): 688-696.

50. Kader AA (2002). Post-harvest Technology of Horticultural Crops. University of California, Agriculture and Natural Resources. Pub. 3311.

51. Antoniali S, Leal PAM, Magalhães AMDe, Fuziki RT \& Sanches J (2007). Physio-chemical characterization of 'Zarco HS'yellow bell pepper for different ripeness stages. Scientia Agricola 64(1): 19-22.

52. Greirson W (2006). Maturity and grand standards. In: WF Wardowski, W.M. Miller, DJ Hall and W. Greirson (eds.), Fresh Citrus Fruits, 2nd Ed. Florida Sci Source, pp 23-48.

53. Palou L, Silva A \& Perez-Gago MB (2015). Antifungal edible coatings for fresh citrus fruit: A review. Coatings 5: 962-986.

54. Kader AA (1985). Postharvest biology and technology: an overview In: Postharvest Technology of Horticultural Crops (AA Kader, ed.). Univ. Calif. Coop. Ext. Service 3311, pp 3-7. 